\title{
The Astronomer Nicolae Donitch, a Pioneer of the International Astronomical Union
}

\author{
Magda Stavinschi \\ Astronomical Institute of the Romanian Academy Str. Cuţitul de Argint 5, \\ Bucharest, RO-040557, Romania \\ email: magda_stavinschi@yahoo.fr
}

\begin{abstract}
Nicolae Donitch gave a special role to Romania's membership of the IAU, even though it had basically adhered to it in 1922, but only on the 12th of July 1928 was Romania's membership in the IAU recognized. He was a passionate observer of eclipses, of the zodiacal light, and a good instrument builder. His tortuous destiny was somehow similar to the destiny of many Romanians from Eastern Moldova: he was born in Chişinău, the capital of Bessarabia at that time; he studied in Odessa; after the first revolution in February 1917 he left Russia and remained in Odessa until the arrival of the Bolsheviks in 1920, who would completely destroy his laboratory. He then moved to his private Astrophysics Observatory in Dubăsarii Vechi, which he had set up in 1908, and stayed until 1940, when Bessarabia was once again torn away from Romania. He relocated to Bucharest, but soon after, when communists came to power, he had to leave the country on a permanent basis. As he severed all the ties with people from the country that had fallen into the red zone of communism, we completely lost track of him. It was only recently that, after thorough research, we could discover his traces, and learn of his last years of life.
\end{abstract}

Keywords. Nicolae Donitch, IAU, Bessarabia, solar eclipses, zodiacal light

\section{Introduction}

On the 28th of July 1919, in Brussels, the most important association of professional astronomers was born and eventually took the name of International Astronomical Union (IAU) or, because the two official languages were even from the very beginning English and French, Union Astronomique Internationale (UAI).

Romania joined this important group, contributing to international science even from the beginning. This happened at a wonderful time, only after a few months since the Romanian provinces conjoined under the name of The Great Romania. On the 1st of December 1918, Transylvania, Bessarabia (Eastern Moldova between Prut and Dniester rivers) and Bucovina joined together to form the Romanian Kingdom, whose frontiers remained unchanged until 1940.

Not only the end of the World War I, that so deeply shook Europe, but also the rebirth of a nation that had suffered so much over the ages, made Romania want to openly join any international collaboration, especially since it meant peace and progress.

Nicolae Donitch was the one who fought so much for this outcome and he represented Romania even from the start within the IAU. He was an astronomer rather unknown to his people, and that maybe because he had the same destiny as the tragic one of his fellow citizens. Only a while ago, we barely knew about the whereabouts and time of his death. He had such a tormented life, he had worked with abnegation and he had made so many sacrifices for the understanding of the universe that I believe that only a novelist could follow his unique destiny. 
As a member of a famous Moldavian aristocrat family, known even from the XVIIth century, Nicolae Donitch (Donici) is famous for the impressive number of eclipses he observed, from Spain to Cambodia, from Portugal to Crimea, from USA to Russia. He studied the zodiacal light, in Egypt, in Algeria and in Romania. He studied comets, the solar system bodies, but especially solar physics; he was a great admirer of Einstein's theory of relativity, even from its appearance in specialized scientific works. He may be considered the first Romanian astrophysicist.

Thus, we have him to thank for Romania's admission to the IAU, but also for the only private Romanian Astrophysical Observatory, founded in the same year - 1908 as the Astronomical Observatory in Bucharest, the current nucleus of the Astronomical Institute of the Romanian Academy.

He was a man who had broken the records of seeing so many eclipses, and yet we did not know that he would enter into the eclipse of his own history; for quite a long time, nobody in our country knew of him.

The events that changed Romanians' destiny took place at the end of December 1989. They also led to an acknowledgment of the values from the past, of those who united us and brought fame to our people all over the world. So it happens that Nicolae Donitch's personality became a primary purpose for many researchers of the past.

All this, as well as the remarkable results of his research, are described in detail in the book recently published by the author of this article, Nicolae Donitch, a Pioneer of the International Astronomical Union, including all the articles written by Donitch and a rich bibliography (Stavinschi 2018).

Taking into account the tormented destiny of the territory between the rivers Prut and Dniester, the access to the archives of the Republic of Moldova was very precious. In 1812, the eastern parts of the Principality of Moldavia, an Ottoman vassal, along with some areas formerly under direct Ottoman rule, were ceded to Imperial Russia. In 1917, in the wake of the Russian Revolution, the area constituted itself as the Moldavian Democratic Republic. Soon after, the parliamentary assembly declared independence, and then it united with the Kingdom of Romania. In 1940, the same area was formally integrated into the Soviet Union, under the name of Moldavian SSR. During the process of the dissolution of the Soviet Union, the Moldavians proclaimed their independence in 1991. Now it is called the Republic of Moldova.

\section{The beginnings}

The Donici family was a special aristocratic family in Moldova. Not all of them managed to face the disasters of history and to leave something behind. But the most remarkable member of this family, at least for the Romanian and universal science, was the astronomer Nicolae Donitch.

He was born on 1/13 September 1874 in Chişinău, the biggest city in Bessarabia, today the capital of the Republic of Moldova. Nicolae was a paternal orphan at the age of two, and double orphan by the age of eight. Elena Macri-Lîsakovskaya, his mother's sister, adopted him and provided him with a remarkable education.

Nicolae was home-schooled by private tutors, but afterwards he became a student to the Richelieu' high school in Odessa, from which he graduated in 1893. After graduating, he became a student to the Faculty of Physics and Mathematics of the Imperial University of Novorossiysk (the New Russia) in Odessa. After finishing his studies at the University of Odessa in May 1897, and receiving the first degree diploma, N.N. Donitch left for St. Petersburg, where he started his scientific career collaborating with the most important Russian astronomers of those times: F.A. Bredikhin, O.A. Baklund and A.A. Belopolsky. At the same time, he started working as a collaborator in the Observatory in Pulkovo. 
Especially, he allocated time to the spectral analysis of stars, and particularly the Sun and the Moon.

On the 27th of April 1898 he was in Odessa, an important port and a significant industrial and cultural centre, from where he sent his first scientific paper that would be published in Astronomische Nachrichten. It concerned the meteorite that had fallen in a German colony, Liebenthal, near Odessa on 7/19 of November 1881.

In 1897 he was elected as a member of the Société Astronomique de France and in January 1899 he became a member of the Russian Astronomical Society.

\section{Before World War I}

At the end of March 1900, he requested the management of the State Council Chancellery, where he worked, to send him to North Africa, in the village of Elche on the banks of the Mediterranean Sea, in order to observe the eclipse of 28th of May/10th of June 1900, the first one seen by him. And since sometimes accidents can happen, just a few seconds before the end of the totality phase, Donitch mistakenly pushed the obturator of the astrograph, and thus one of the slides has the intense reproduction of the corona, whereas the second reproduction was not that clear.

In April 1901 a minimum of solar activity was anticipated, and many observers of the Sun were redirecting their instruments towards it. In order to obtain better results, they formed different study groups, including a Solar Commission within the Société Astronomique de France. From 1901 until 1916, Donitch was the delegate of the Imperial Academy of Sciences for all astronomical expeditions.

On the 18th of May 1901, he observed another total solar eclipse, this time in Sumatra. Contrary to the previous one, it would be exceptionally long, maybe one of the longest that could take place on Terra. He left St Petersburg for Padang, an Indonesian city on the Sumatra Island. The expedition did not have the expected success on the day of the eclipse, as the sky was covered by heavy stratocumulus clouds. Fortunately, around 10 o'clock, the clouds started spreading away and the first contact was visible. Two days later, he had developed all the slides and he sent to the Academy the following cable: "Eclipse observed in Padang through cirri, 6 photos, and corona according to the minimum activity".

The laboratory experiments and his observations during the total solar eclipses led the Imperial Academy of St. Petersburg to send him to work in the Observatory in Odessa, a branch of the Observatory in Pulkovo. From 1902, he was member to the Imperial Academy of Sciences in St Petersburg.

During June-October 1902, Donitch stayed in Odessa in order to research a new method of recording the spectrum of the solar chromosphere with a circular slit. He would then apply this method in his expedition to Mont Blanc and Evian le Bains. As usual, he was deterred by no obstacles, no heights and no distances in order to fulfil his astronomical mission. The observations he made at the altitude of Mont Blanc confirmed his hypotheses.

On the 21st of October 1902, an important group of sunspots was recorded, and that signified a need for revitalizing the international activity in order to observe the phenomenon, including the homogenization of the methodology used, especially since none of the eclipses in 1902 was total (the ones on the 8th of April, the 7th of May and the 31st of October were partial).

On the 22nd of January 1903, he presented information regarding the status of solar layers during the period of its last minimum of activity, registered at the start to the year of 1900, and using the data obtained during the observation of eclipses on the 28th of May 1900 and 18th of May in Padang in Sumatra. 
In March 1904, he left for Phnom-Penh in Cambodia in order to observe an annular solar eclipse from 17 of March of about $8 \mathrm{~m}$ 07s. It was a successful observation to which were applied, for the first time, the results obtained from de La Baume Pluvinel at the observation of the annular eclipse in Cairo on the 11th of November 1901. Having the advice of the Russian astronomer F.A. Bredikhin, Donitch thought about photographing the photosphere at such an event.

On 29-30th of August 1905, a new solar eclipse occurred, a total one this time, expected to last $3 \mathrm{~m}$ 46s. The two missions organized by the Imperial Academy of Sciences in St Petersburg had as object the study of the chromosphere and corona, and also the study of the variation of elements of terrestrial magnetism, each accompanied by meteorological observations. Donitch was charged with managing the first mission. As observations station, the following were chosen: Alcala de Chivert (where Donitch went together with the baron von der Pahlen; the first one observed the spectra, and the second one photographed the corona and provided the meteorological service) and Aswan in the south of Egypt, where the solar corona was photographed by Oculici and Baikov. Although in Alcala the sky was not that clear at the beginning, in Aswan it was perfect. Donitch also observed the green coronal ring.

The Imperial Academy of Sciences in St Petersburg sent him to represent it in the Commission of eclipses for the following triennium: 1907-1910. In May 1907, Donitch participated in the first congress in Meudon at the Union Internationale pour les Études Solaires. This Union may be considered as a forerunner of the International Astronomical Union, founded in 1919.

1907 is the year of the first expedition to Upper Egypt. On 1/14 November 1907, he observed in Upper Egypt the transit of Mercury over the disk of the Sun, having been sent on this mission by the same Academy. On the 1st of April 1908 was founded, in Bucharest, the Astronomical and Meteorological Observatory, which later became the Astronomical Observatory, and in 1990 the Astronomical Institute of the Romanian Academy.

Even in the same year, Nicolae Donitch would set up on his aunt's land in Dubăsarii Vechi, the first Astrophysical Observatory, on the right bank of the Dniester. It was a great progress for that time, not to mention that it was a private one. Concerned with the study of the Sun, Donitch started acquiring various specific instruments even from 1898, namely when he was only 24 years old. Even though, at the start of his scientific activity, he worked in Odessa or St Petersburg, he truly wanted to have his own Observatory, his own instruments and his own scientific programmes. In those times, astrophysics was only at its beginnings, and Romanian astronomers, receiving French education, were mostly preoccupied with celestial mechanics and astrometry.

His activitiess and remarkable talent for instrumental equipment were remarked on by the French astronomer, Pierre Salet, who mentioned him in his book Spectroscopie astronomique (Salet 1909).

The fourth Assembly of the International Union for Co-operation in Solar Research took place between the 29th of August and the 3rd of September 1910 at Mount Wilson, California, under the administration of the Solar Observatory of the Carnegie Institution (Fig. 1). The Union had been created six years earlier, and there still was no other international organization that could stimulate the interest for solar physics.

The first congress of this Union had already been held in Meudon in May 1907. The Union may be considered as the forerunner of the International Astronomical Union.

It was truly a remarkable congress; participants delegated from 50 observatories and laboratories from 13 countries participated. N. Donitch was mentioned as a professor at the Observatory in the University of St Petersburg, Russia. He was appointed to the committee for the organization of eclipse observations. 


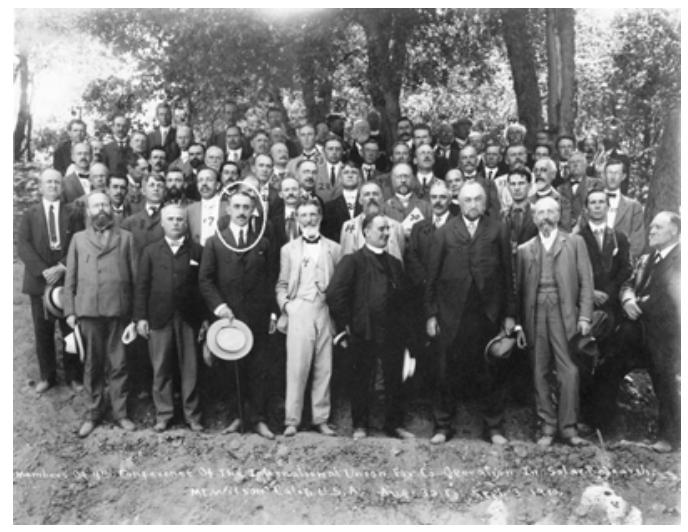

Figure 1. International Solar Union meeting at the Solar Observatory, Carnegie Institution, Mt Wilson, 1910.

In 1910, a celestial phenomenon that had been extremely anticipated and covered in the media took place. It was believed to be the most famous periodic comet of all times, Halley's Comet. Obviously, Donitch could not avoid such an important phenomenon. The observations he made led him to build in the following years a new instrument called "a comet triplet". Its purpose was to observe solar and lunar eclipses and to photograph stellar bodies, obtaining wide-field stellar spectra in different spectral regions.

In 1912, the Imperial Academy of Sciences in Russia gave Donitch another mission: to organize the observation of the central solar eclipse (it was a hybrid eclipse, at first total and then annular) that was to take place on 17 April 1912. Its maximum was at the time it crossed over the Atlantic, near the Portuguese sea coast, where there were the best chances for a clear sky. This is the reason why he chose to stay in the Portuguese city of Ovar. Donitch enrolled soon after in the Tsarist Army for the fights that were about to begin, and thus the report on the expedition was presented in the Russian Academy by the academician A.A. Belopolsky on the 9th of May 1917, in the absence of the author, who was enrolled for military service.

The fifth conference of the International Union for Co-operation and Solar Research was held in Bonn, between the 30th of July and 5th of August 1913. The Report of the Committee for the organization of observations during eclipses was presented by the Count de La Baume Pluvinel. He made a short description of the results obtained during the last total and annular eclipses (total eclipses on the 3rd of January 1908 and on the 8th of May 1910) and mentioned a certain project for the observation of the eclipse in 1914. It was mentioned that astronomers who wanted to go to Russia must talk to Doctor N. Donitch and specify the load of the instruments they would carry with them.

Donitch would also be named in the Organizing Committee for the observation of eclipses, managed by Sir Normal Lockyer, having as secretary the Count de La Baume Pluvinel. Donitch was a member of the third commission for the solar atmosphere, namely of the Photographical Section, and also of the fifth commission for the organization of Eclipse observations.

The Union ended its activity because of the war, and its mission would be taken over by the IAU, founded in 1919.

Starting with 1914, Nicolae Donitch became a member of the Astronomische Gesellschaft.

On 8/21 August 1914 it was another total solar eclipse. Even though it did not last very long $(2 \mathrm{~m} 14 \mathrm{~s})$, it was observed from many places and had encouraging meteo forecasts. Let us not forget that the World War I had only just begun and thus many missions were 
not concluded. The Pulkovo Observatory had prepared three expeditions: Riga, the area of Kiev and Feodosia. The mission managed by N. Donitch was to go to the Feodeosia city on the southern coast of Crimea. Fortunately, the weather was exceptional. For Donitch, it was the sixth eclipse he had observed.

Also, in 1914, the Imperial Academy in St Petersburg gave Donitch the mission to observe the transit of Mercury over the disk of the Sun on the 7th of November 1914 (12h $3 \mathrm{~m}$ UTC) in Algeria. He would continue to observe such phenomena every time he had the opportunity.

After the tragic spring of 1917 nothing could be recovered. Let us not forget that the Russian Revolution from February 1917 led to the abdication of the Tsar Nicholas II in favour of his brother and it preceded the Russian Revolution from October, when the Leninist (Communist) regime was installed.

Obviously, Donitch was greatly affected by the Revolution from February 1917. In May, he left St Petersburg, leaving everything behind: instruments, documents, books, everything! Odessa was also a victim of these tragic events. At the start of February 1920, the troops of the Red Army entered Odessa and Soviet power was installed. Odessa became the centre of the province with the same name.

He still managed to observe the total lunar eclipse from the 4th of July 1917 in his Observatory from the Dubăsarii Vechi.

Following the Bucharest Treaty from 16/28 of May 1812, Bessarabia was no longer a Romanian territory. It was a major change for the Romanians over the river Prut, and a major change for Nicolae Donitch's life too, after he ran from Soviet Russia following the events of 1917.

During the winter of 1918-1919, Donitch prepared the expedition for the observation of a new total solar eclipse that he would observe on the 29th of May in Brazil. However, the plans were cancelled "due to the sudden occupation of the city of Odessa by the Bolsheviks. Moreover, due to the disorder caused by the evacuation of the city and the Bolshevik forces that were approaching Odessa", he left all his necessary instruments at the University.

Between 1917 and 1923, the Russian Civil War took place, carried among "the Red" who were communists and revolutionaries and "The White", monarchists, conservatives, liberals and socialists, opposers of the Bolshevik revolution. Sometimes, during this period, Donitch had visited Russia and met at the Dubăsarii Vechi the astronomers on the right bank of Dniester. He settled for more than two decades in his Observatory, that he had founded in 1908 on his aunt's land in the Dubăsarii Vechi.

\section{Pioneer of the International Astronomical Union}

In 1919, the IAU was founded, with the purpose of regrouping several projects from those times: the Carte du Ciel, the Solar Union and the Bureau International de l'Heure (BIH). It was also a way to unite countries that had fought together or against each other during the World War I. It seems that, when the IAU was founded, political circumstances were considered more than the spirit of scientific co-operation.

In the beginning, the IAU had 207 members from 19 countries, compared to more than 12000 from more than 70 countries, as is the case today. The end of World War I brought a new wave of interest for scientific issues, and for the astronomical ones, many with immediate applications.

In July 1919, in the Palace of Académies in Brussels, scientists from the allied countries gathered. They decided upon creating four unions: the International Union of Geodesy and Geophysics, the International Union of Pure and Applied Chemistry, the International Union of Radio Science and the International Astronomical Union, grouped within the International Council for Research. Bureaucracy and the 
difficulties for re-establishing peace meant that these unions became operative only in July 1920.

In 1921 B. Baillaud, the first president of the IAU, wrote to the Romanian Academy, insisting on the necessity that Romania must adhere to the Union:

"According to the statute of the IAU, a general assembly of this Union will be held at Rome, on the 20th of April 1922. The executive committee stresses on the great interests that the adhesion of the States mentioned in article 3 from the Statute of the International Council for researches that have not yet adhered. The whole world suffered delays due to the complications produced by the war. We believe that delays, long in certain cases, would be necessary in order to receive the fees. Without a doubt, the most essential thing now is to have moral adhesion that could allow the countries that have paid the fees to send regular delegations at the general assembly so that they could participate in discussions, in accordance with the statute. We trust that you will answer us as soon as possible, and you will be close to us, now in peace time, as you were during the war."

1922 was maybe one of the most significant years in Donitch's life. During a meeting of the Romanian Academy, it was mentioned: "it admitted within the plenary session from the 20th of January 1922, to morally participate to different International Unions, the Academy must also participate in the Union Astronomique Internationale in the same conditions as in the Union Géodésique et Géophysique Internationale, and to make the necessary interventions".

On 31st of March 1922, the president "presented Mr. N. Donitch to the Academy, the astronomer who, for several years, set up and led by his own means the astrophysical Observatory from the Dubăsarii Vechi, on the Dniester banks in Bessarabia. Mr. Donitch's activity and scientific works are familiar to the universal scientific world and now, together with Bessarabia, he came back to his motherland and the Academy took the necessary measures, mentioned in the previous sessions, in order to assure the functioning of the Observatory and Mr. Donitch's scientific activity." In the same year Donitch was elected an honorary member of the Romanian Academy.

In May, Donitch participated in the first IAU General Assembly in Rome, that would take over, to a large degree, the mission of the old International Union for Solar Research, that had ended its activity due to the start of World War I.

Donitch was one of the 83 participants, as Romania's delegate. He was elected for the following three years to the Commissions for solar physics, and the Physical observations of planets, comets and satellites.

In his report sent to the Romanian Academy, Donitch announced Romania's adherence to the IAU. Among the few participants that would present their recent results was also N. Donitch, who resumed his studies on the solar atmosphere and showed photographs taken by the big refracting telescope and the spectroheliograph at the Observatory in Dubăsari.

He ended his report on a sad note: "Regarding the organization of the IAU, it is, without a doubt, worthy of praise, but [...] it must allow this Union to shortly include all civilized countries in the world." Let us not forget that it was the first general assembly after the war, when few thought of science and even fewer to giving financial support, especially since it was almost impossible in some cases, given the disaster that had just shaken the world.

In July 1925 the 2nd IAU General Assembly was organized in Cambridge (UK). There were 250 years since the foundation of the famous Observatory in Greenwich, a good occasion for gathering the members of the new IAU that had just been founded, for the second general assembly. Donitch represented the Romanian Academy (Fig. 2). 


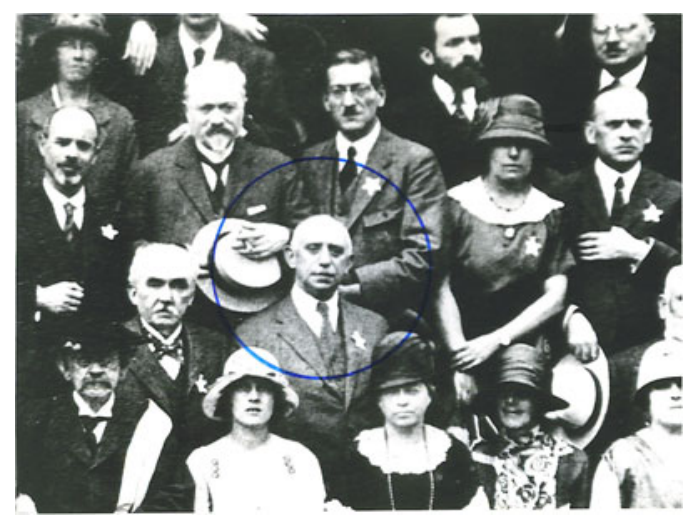

Figure 2. International Solar Union meeting at the Solar Observatory, Carnegie Institution, Mt Wilson, 1910.

He was re-elected to the Commissions No. 12 and 16. He had always some special proposals to make at all IAU general assemblies, proving to be extremely active among the colleagues in this prestigious international organisation.

In the meeting of the Romanian Academy from the 1st of April 1927, it was announced that, among other foreign associations, the invitation of the IAU to participate in its activities was received, Romania being regularly represented until then by Nicolae Donitch. The Government could assume that the issue of financing it being a "question of national prestige".

Reminding the Academy's obligations towards different international organisations, the president mentioned that it "has created its obligation to pay the annual fees, an obligation that we cannot cope with due to the lack of means. [...] In the past years, our honorary colleague Mr. N. Donitch represented the Academy at the Congresses of the IAU. Our colleague will not be able to participate this year in the name of our Institution because we have not paid the last year's fees."

The third IAU General Assembly took place in Leiden, between the 5th and 13th of July 1928, to which Donitch participated as representative of the Romanian Government.

On this occasion also the terrible War cannot be forgotten. As Donitch mentioned, "Out of these speeches one can sense the gratefulness regarding the decrease - most visible lately - of reciprocal hatred among the people that have fought against each other, a hatred that had unfortunately involved the scientists too. All speakers have expressed their hope in the collaboration of the scientists gathered here in Leiden, a collaboration that only sees as purpose the development of science and which will lead to the consolidation of good relations."

He was to play a special role in Romania's adhesion to the IAU, even though it had basically adhered to it in 1922, but only on the 12th of July 1928 was Romania's membership in the IAU officially recognized. "... the International Research Council, gathered in Brussels, had notified the General Assembly that Romania had definitely adhered to this Council too. This news, communicated to the gathering by its president, was unanimously received with applause by the entire public."

\section{Solar eclipses}

On the 9th of May 1929, a new total solar eclipse took place, and Donitch thought that the best place to observe it would be in the English town Georgetown, where the totality phase would be of $2 \mathrm{~m} \mathrm{40s}$. The inconvenient thing was that in May the rainy 
season started. Since it was not possible for Romania to organize its own expedition, Donitch observed a partial eclipse from his Observatory.

During the autumn of 1929, he left for Egypt to study the zodiacal light, a theme of research that will concern him until the end of his life. He came back in the middle of March 1930. The Ministry of Public Instruction included in the budget for 1931 the amount requested by Donitch "so that he could continue, during January and February 1931, the observations he started in the south of Egypt (Aswan) regarding the zodiacal light, with the purpose of verifying the conclusions of Einstein's theory."

The fourth IAU General Assembly was especially held, in 1932, in Cambridge (Massachusetts, USA) in order to offer the participants the chance to observe the total solar eclipse of the 31st of August, whose totality tracked crossed the USA and Canada, with a totality duration of $1 \mathrm{~m} 30 \mathrm{~s}$. The weather was not that fine, but the specialists had the occasion of sharing their experiences.

Donitch talked about his observations from Cape Porpoise (Maine), a small fishing village on the coast of the Atlantic Ocean, where the eclipse lasted $1 \mathrm{~m}$ 20s. He was reelected to three commissions of the IAU: Chromospheric phenomena, Solar eclipses and the commission for Physical observations of planets, comets and satellites.

The following IAU General Assembly took place between the 10th and 17th of July 1935 in Paris, in the presence of the president of France, Albert Lebrun. At the end of the solemn meeting, the president of France opened the Exhibition of astronomical instruments, documents and photographs to which the Observatory in Dubăsarii Vechi participated with the slides of the photos taken by some instruments in the Observatory, namely the spectroheliograph and coelostat, but also slides of the chromosphere and the prominences obtained by means of these instruments.

On the 19th of June 1936, the last solar total eclipse he observed took place in Inebolu in the Black Sea region of Turkey. The maximum of the eclipse (Siberia) was 2m 31s. The duration in Inebolu was shorter than in other parts $(1 \mathrm{~m} 15 \mathrm{~s})$, but the chances of clear sky were high (50\%). Unfortunately, before the start of the totality phase of the eclipse, a heavy cloud hid the Sun, while the rest of the day was clear. Thus, the team could not undertake the proposed programme.

Finally, the last IAU General Assembly in which Donitch participated was the sixth one, which took place in Stockholm, between the 3rd and 10th of August 1938. Within the Zodiacal Light Commission, he presented the observations he had made in Aswan (Upper Egypt) during the winters of 1929-1930 and 1932-1933. The report was signed on the 1st of June 1940, only a few days before the rupture of Bessarabia from Romania.

\section{Year 1940 , a dramatic turn in his life}

The year 1940 was a tragic one for the Romanians: on the 28th of June, Romania was summoned by the Soviet Union to evacuate the civil administration and the army on the territory of Bessarabia. In 1940, Bessarabia was assigned by means of an ultimatum to the Soviet Union. In order to avoid war, Romania accepted the ultimatum and Bessarabia was lost, becoming the Moldavian Soviet Socialistic Republic. In only a few days, over 200000 inhabitants of all ethnicities had taken refuge in Romania. Donitch's family did the same; he and his wife moved in Bucharest.

On the 21st of June 1941, the Romanian troops allied with the German army crossed the border of the Soviet Union with Romania and took over Bessarabia. After the release of Bessarabia by the Romanian-German troops, in the summer of 1941, the scientist came back to Dubăsari and did not find anything left. The Russians had destroyed the house and the Observatory.

He came back to Bucharest but after the bombing from April 1944 he decided to leave the country. 
In July 1945, Donitch came to France. Even though he was by now a septuagenarian, the respect and admiration he received in the international scientific world led André Danjon, the director at that time of the Observatory in Paris-Meudon, to hire him immediately and give him some observation missions in Egypt for the study of zodiacal light and to participate in the IAU General Assembly in Dublin (1955).

The documents obtained by courtesy of the French National Centre for Scientific Research - the CNRS archive - brought us information regarding his scientific activity, but also regarding Donitch's personal life until his death.

In November 1945, his individual file was made, being a member of the Astrophysics Section, The Physics of the Globe, and was presented to André Danjon, the director of the Observatory.

He made a short description of the issues he approached and the results he obtained. This is, maybe, the best presentation of his activity until then: observations of total solar eclipses in 1900 (Spain), 1901 (Sumatra), 1905 (Spain and Upper Egypt), 1914 (Crimea), 1932 (USA), of the annular eclipse in 1904 (Cambodia) and the solar eclipse, called central, in 1912 (Portugal); observations of the solar eclipse with a spectrograph with circular slit in the Odessa Observatory (1902) and Janssen Observatory on Mont Blanc peak (1903); observations of Mercury's transit across the solar disk in 1907 (Upper Egypt); observations of the spectrum of Halley's Comet (1910); observations of the zodiacal light (the winters of 1929-1930 and 1932-1933, Upper Egypt); founding an astrophysical observatory in Dubăsarii Vechi (Romania).

Thus, the first direct support from the CNRS came at the end of 1945, when he obtained the support for the immediate research of the zodiacal light in the Observatory of Meteorology and Physics of the Globe in Southern Algeria, in Tamanrasset, in the mountain range Hoggar, in the south-west of Algeria at an altitude of $1400 \mathrm{~m}$, in the middle of the Sahara Desert. He had a clear sky experience in Egypt during the winters 1932-1930 and 1932-1933, and considered repeating the experience again in Africa, this time in Algeria.

The first out of the four expeditions took place in the winter of 1945-1946, and the next one took place in the following winter. The main purpose was to study the zodiacal light, being a member of the IAU Commission dedicated to this scientific topic, popular during those days.

In August 1948, the Romanian Academy was reorganized. Following the Decree regarding the transformation of the Romanian Academy into the Academy of the Romanian People's Republic, in the list of its members, 113 former full members, honorarymembers and correspondents, were not found: politicians, some already arrested or who had recently left the country. One of them was Nicolae Donitch.

The letter from the general director from the 6th of July 1949 mentioned a support fund for "the scientists that carry on with their research", due to the persevering work done by a lonely man at 75 years old!

In the report of the General Assembly of the IAU, that took place in Rome in September 1952, Donitch was mentioned again as a member in Commission 22 for Meteors, zodiacal light and analogous issues, and in the Subcommission regarding nocturnal sky and zodiacal light.

The next official letters "suggested the renewal of the work subvention for Mr. Donitch, who, according to his habit, works slowly but seriously."

The last manuscript, in which he analyzed the 43 photos of the zodiacal light obtained during the four expeditions in Tamanrasset, would be received by the SAF editorial office on the 2nd of November 1954.

On the 28th of August 1955, F. Baldet sent to A. Danjon the last report made by Donitch, and he mentioned that he would leave for the IAU Congress in Dublin together with Donitch. 
"Even though being of advanced age and having a precarious state of health, Mr. Donitch was able to leave for Béni-Abbès together with his instruments that he had to modify in Alger in order to continue with his researches on the zodiacal light. [...] Considering the fact that he had dedicated his whole life to astronomy and seeing the financial difficulties of an old age without income sources, it would be highly recommended that CNRS could renew his subvention that he requests as financial help for the old scientists."

In November 1959, Donitch filled in, with almost unrecognizable hand-writing, the last individual file in which were mentioned only the birth date, his Romanian nationality, the fact that his was an honorary member of the Romanian Academy and of the the Institute in Coimbra (Portugal). The scientific works he mentioned were: "photographic observations of the formations of the exterior solar atmosphere (The zodiacal light) in Tamanrasset (Hoggar) during four consecutive winters (1946-1949, missions sponsored by $\mathrm{Mr}$. A. Danjon, director of the Paris Observatory)".

In the file from the 15th of December 1959, his hand-writing can be noticed only for the date and the signature (the rest was typewritten). On the 21 st of November 1960 , namely on the day of his death, the CNRS sent him a letter in which it requested Donitch to fill in the form necessary for the approval of the indemnity.

His death certificate, which was just discovered, is from a retirement home PugetThéniers, a commune in the Alpes-Maritimes department, from 22nd of November 1960.

\section{Discussion}

Ros: Did you plan to distribute information in Romanian schools so that Romanian students know the work of this astronomer?

Stavinschi: Yes, we have a Romanian "version" of the book. I call it "version" as it includes some details that are only of national interest. Anyway, I consider history of astronomy very useful for education!

\section{References}

Salet, P. 1909, Spectroscopie astronomique, (Paris: eds. Octave Doin et fils)

Stavinschi, M. 2018, Nicolae Donitch, a Pioneer of the International Astronomical Union, ed. Eikon, Bucharest, Romania 